\title{
Corporate Social Responsibility Disclosure and the Value Relevance of Annual Reports for Listed Banks in Kenya
}

\author{
Gitahi J. \\ Nasieku T. (PhD) \\ Memba F. (PhD) \\ Department of Economics, Accounts and Finance, \\ Jomo Kenyatta University of Agriculture and Technology, Nairobi, Kenya
}

Doi: 10.19044/esj.2018.v14n4p329 URL:http://dx.doi.org/10.19044/esj.2018.v14n4p329

\begin{abstract}
This study investigated the relationship between corporate social responsibility disclosure and value relevance of annual reports for listed banks in Kenya. To do so, the study used content analysis and financial analysts' perception to quantify corporate social responsibility disclosure, included by banks in their annual reports. The sample comprised of the annual reports of ten banks listed on the Nairobi Securities Exchange (NSE) over the entire period from year 2010 to year 2015. The study focused on banks due to additional regulation by the Central Bank of Kenya, (CBK). A survey research design was adopted. The study used both primary data and secondary data. Primary data was obtained through survey questionnaires administered on respondents who were financial analysts at a total of sixty one Kenya's Capital Markets Authority (CMA) licensed firms (investment banks, stock brokers, fund managers and investment advisers) as at 30 April 2016. Secondary data was obtained from the corporate action register and handbook by the Nairobi Securities Exchange, the daily market statistics from the NSE data and annual reports released by the banks. Content analysis program ATLAS.ti 8, OneLook dictionary and Ms Excel 2007 were used for content analysis. Data analysis was carried out using SPSS version 20 and Stata 13. Descriptive statistics and inferential statistics were used for analysis. The results revealed that corporate social responsibility disclosure had a positive and significant relationship with value relevance of annual reports which was measured by the average market price per share, (MPS). This study therefore concluded that corporate social responsibility disclosure in annual reports of listed banks in Kenya affect the value relevance of the annual reports. The study recommends an expanded role of the auditor in reviewing the corporate social responsibility disclosure and other accounting
\end{abstract}


narratives. Currently in accounting reporting, the auditor is not obligated to formally audit accounting narratives. Instead, an auditor reviews the accounting narratives to ascertain if the narratives are consistent with the financial statements. The study also recommends more guidelines and regulations in relation to non-financial disclosures to ensure that firms put clearer information in the hand of investors.

Keywords: Value relevance, corporate social responsibility disclosure, accounting narratives, non-financial disclosures

\section{Introduction}

\section{Background of the Study}

The users of annual reports are those groups identified as having reasonable right to the information contained therein and whose information needs should be recognized. Annual reports provide vital information to varied users. Investors use them for investment decisions; regulators use them to determine whether existing provisions are adhered to, while government and government agencies use them for tax purposes and national statistics, among others (Adedeji \& Kajola, 1998). According to Meyer (2007) accounting plays a significant role within the concept of generating and communicating value of companies. Today, accounting information is mainly disseminated by firms through annual reports. Meyer (2007) noted that annual reports still remain the most important source of externally feasible information on firms. It has been claimed that information disclosed in annual reports is the main factor that most investors consider when making decisions (Wang, Gang \& Chao, 2013).

Accounting information in a firm's annual reports depicts the firm's economic status. According to Weygandt, Kieso and Kimmel (2003) accounting information can be financial or non-financial. International Accounting Standard Board, (IASB) (2011) defines financial information as information about a reporting entity's financial condition included in the basic financial statements, namely, statement of financial position, statement of comprehensive incomes, statement of changes in equity and statement of cash flows. Non-financial information is any information that does not have to be included in the IAS 1 description of financial statements (Ronnie, 2009). Non-financial information, also referred to as narrative accounting, may not be expressed in numbers or financial figures and it can have financial-statement relation or not (Thomas, Céline, \& Ludwig, 2013).

According to Aboody, Hughes and Liu (2002) the ability of accounting information to capture or summarize information that affects share values is called value relevance. The term 'value relevance' is believed to have been first used by Amir et al. (1993) although the literature 
on the value relevance concept extends back to the nineteen sixties with early contributions by Ball and Brown (1968) and Beaver and Dukes (1972). Accounting information is deemed to be value relevant if it has a relationship with equity market value and, if it increases the power of the estimating equation in estimating market values (Barth et al., 2001).

Studies on value relevance of annual reports are stirred by the fact that quoted companies use annual reports as one of the major media of communication with stakeholders (Vishnani \& Shah, 2008). Recurring global financial crisis, for example, the collapse of leading corporations in United States and Europe in 2001-2002 which brought about the largest insolvencies in history (for example, Global Crossing, WorldCom, Adelphia Communications, Enron and Tyco International) and the 1998 wave of financial crisis in the Russian, Asian and Brazilian economies which later threatened the steadiness of the global financial system, brings about turbulent time in stock markets across the world. This has over time raised sharp questions on the value relevance of annual reports. Organization for Economic Co-operation and Development, (OECD) (2004) and Claessens (2006) notes that it is widely believed that these series of events are triggered by the deficiencies in the accounting information reported in annual reports.

Oyerinde (2011) observed that there is a perspective that accounting theory and practice have failed to keep pace with the rapid economic and technological changes which invariably impact on the value relevance of annual reports. The argument is that financial figures are less relevant in assessing the fundamental market value of companies. Lev (2000) in a book, "Intangibles - Management, Measurement, and Reporting", assessed the impact of intangibles on firms' performance and market values. The author details case studies and real-world examples on management difficulties, risk, questions of property rights, marketability, and cost structure to demonstrate that on average about $80 \%$ of the market capitalization can be attributed to intangible asset, whereas only $20 \%$ to the tangible assets underlined in financial metrics.

Ocean (2015) carried out a study, "Intangible Assets Increase to 84\% of the S\&P 500's Value in 2015." The study involved a review of intangible assets of S\&P 500's, which represents 75\% of the American equity market by capitalization. The author concluded that intangible assets represent $84 \%$ of total value. The study further notes that this value represents a growth from 52\% in 1985. There is a common agreement among both scholars and practitioners that corporate value is not adequately depicted in traditional financial statements because of the inability of these reports to take into account the value stemming from, especially, intangible assets.

This inability is said to increase information asymmetry and, thus, cause an impairment of the efficient allocation of resources on the stock 
market (Kristandl \& Bontis, 2007). To correct the information asymmetry that exists between managers and investors, experts have argued that nonfinancial disclosures forms or should form a progressively vital part of annual reports for investor decision-making (Belinda \& David, 2008). Consequently, accounting regulators have revised existing and/or produced new reporting standards or rules which require entities to include non financial disclosures in their annual reports (Topazio, 2013). While firms are obliged to report their revenues, profits and losses, assets and liabilities, they have been able to choose whether or not to report on things like their social and environmental impacts, composition of management, and risk among others. Non-financial disclosures have been voluntary across the world and where some form of regulation or guideline exists, there has been lack of harmonization of such regulation (Daniel, 2015).

The prudential regulations by CBK require inclusion of non financial disclosures by banks in their annual reports. The requirement is that the scope and content of information provided should be of appropriate size and nature relative to a bank's operations (Cytonn, 2015). The additional requirement to include non-financial information has occasioned consistence in the pattern and nature of non-financial disclosures in the annual reports released by banks. This consistence in non-financial disclosures by banks has made it possible to carry out a study on how non-financial disclosures impact on the market prices of the shares of quoted banks.

The growth in the number of regulatory initiatives requiring nonfinancial disclosures has occasioned studies on the value relevance of nonfinancial disclosures. Alan, Donald, and David (2006) explored whether there is any relationship between social responsibly disclosure and the financial market performance of the UK's largest companies. Two data sets were used in the study. The Centre for Social and Environmental Accounting Research, (CSEAR) database of UK companies provided the social and environmental disclosure component. The second data were the stock market returns earned by the largest UK companies as listed by the Times 1,000. A series of statistical tests was performed to examine whether any relationship could be detected in either the cross sectional or longitudinal data over a period of ten years. The study concluded that no direct relationship between share returns and the disclosure was found and that neither had such a relationship been expected, in keeping with the prior literature.

Jones, Frost and Der Laan (2009) studied the market returns and financial performance of entities engaged in sustainability reporting in Australia. The study observed a negative and weak association. In a study "Are Stock Markets Influenced by Sustainability Matter? Evidence from European Countries", Moneva and Ortas (2008) found no association between corporate social responsibility disclosure and share returns. 
Dan, Oliver, Albert and Yong (2011) carried out a study on voluntary non-financial disclosure and the cost of equity capital in which they specifically focused on examining a potential benefit associated with the initiation of voluntary disclosure of corporate social responsibility. The study found out that firms with a high cost of equity capital in the previous year tend to initiate disclosure of corporate social responsibility activities in the current year and that initiating firms with superior social responsibility performance enjoy a subsequent reduction in the cost of equity capital. Further, initiating firms with superior social responsibility performance attract dedicated institutional investors and analyst coverage. They also deduced that firms exploit the benefit of a lower cost of equity capital associated with the initiation of CSR disclosure.

In a study "Corporate Social Responsibility, Customer Satisfaction, and Market Value", Xueming and Bhattacharya (2006) sought to establish whether corporate social responsibility disclosure affect the market value of a firm. Based on a large-scale secondary data set, the results showed that corporate social responsibility disclosure affect the market value of firms.

It is notable that existing studies have yielded contradictory inferences or inconclusive findings on the value relevance of corporate social responsibility disclosure and in general, narrative accounting. This has also been noted by for example Aylin, Tuba and Lale (2014); Dhiaa (2012); Ibadin and Oladipupo 2015; Koedijk and Ter Horsta (2010); Thomas et al. (2013) and Vijitha and Imalathasan (2014).

\section{Statement of the Problem}

Firms derive their value from the market's expectations of their performance. Accounting provides the necessary information for the market to form these expectations (Benoit, Colletaz, \& Hurlin, 2014; Ohlson, 1999; Swati, 2016). Over time experts have observed the difference between a firm's total value as measured in stock price and the value of its tangible assets underlined in financial metrics. On average about $80 \%$ of the market capitalization can be attributed to intangible asset, whereas only $20 \%$ to tangible assets underlined in financial metrics (Lev, 2000; Ocean, 2015). To correct the information asymmetry that exists between managers and investors, experts have argued that non - financial disclosure forms or should form a progressively vital part of annual reports for investor decision-making (Belinda \& David, 2008). Consequently, accounting regulators have revised existing and/or produced new reporting standards or rules which require entities to include non - financial disclosures in their annual reports (Topazio, 2013).

However, studies on the value relevance of non-financial disclosures have yielded contradictory inferences or inconclusive findings. For example, 
in studies on the value relevance of corporate social responsibility disclosure some studies have concluded that there is no relationship between the corporate social responsibility disclosure and market value equity (for example, Alan et al., 2006; Jones et al., 2009; Moneva \& Ortas, 2008). On the other hand, some studies have observed a relationship between the corporate social responsibility disclosure and market value equity (for example, Dan et al., 2011; Xueming \& Bhattacharya 2006).

What is more, many value relevance studies on non-financial information have been done in developed countries such as Europe and Northern America. Value relevance studies on non- financial information have neglected developing countries (Dhiaa, 2012). Negah (2008) points out that value relevance studies on non-financial information in emerging economies are limited and therefore the impact on stock price behaviour in these economies still remain an unanswered question. In view of the contradictory inferences or inconclusive findings in the existing literature, this study sought to extend the line of research on value relevance by determining whether corporate social responsibility disclosure have a relationship with value relevance of annual reports for listed banks in Kenya.

\section{Literature Review}

\section{Theoretical Background}

Different theories have been used in value relevance research. Signaling theory has been used to explain the relationship between accounting disclosures by a firm and the market value of its equity. Originally developed and used to explain information asymmetry in labour markets, the signaling theory shows how this asymmetry can be reduced by the party with additional information signaling it to others. The theory provides a unique, practical, and empirically testable perspective on problems of social selection under conditions of imperfect information (Connelly, Certo, Ireland, \& Reutzel, 2011). According to Alvarez, Sanchez, and Dominguez (2008) a signal can be a visible action or a structure used to indicate the sign of quality. Typically the sending of a signal is grounded on the basis that it should be positive to the signaler.

Agency theory have also been widely used to explain and understand disclosure phenomena by accounting researchers in many countries with diverse social, political and economic backgrounds (for example, Depoers, 2000; Inchausti, 1997). Ittonen (2010) observe that current mainstream accounting research is based extensively on economic models of agency that represent the operating company (firm) manager as the "agent" and the individual investor as the "principal". The agency theory is generally concerned with the principal-agent relationship between the principals (for example, owners) and the agents (for example, the managers). 
Accounting scholars have also particularly employed legitimacy theory widely as an explanatory theory to describe the motivations behind voluntary corporate social and environmental disclosures (for example, Laan, 2009, Nik Ahmad \& Sulaiman, 2004; Watson, Shrives, \& Marston, 2002). Indeed, Van der Laan, (2009) observed that beginning early 1980s, the theory has been used by researchers seeking to explore social and environmental accounting practice.

The capital need theory has also been used by researchers to explain the reasons behind the disclosure of information by firms. Gray, Kouhy, \& Lavers, (1995a) noted that the theory implies that managers have an incentive to disclose additional information that enables them to raise capital on the best available terms. According to Healy \& Palepu, (2001) firms' managers who are intending to transact in capital market have motivations to disclose information voluntarily to decrease the information asymmetry problem and thus decrease the external financing cost. The capital need theory predicts that increased voluntary disclosure of information by the managers will lead to lower cost of capital through reducing investor uncertainty (Schuster \& O'Connell, 2006). Consequently, more voluntary information disclosure is preferable to less, in order to decrease the uncertainty surrounding a company's future performance and to assist trading in shares (Hassan, Giorgioni, Romilly, \& Power, 2011).

\section{Empirical Literature Review}

Over four decades ago, value relevant of accounting information became the focus of accounting research. Literature probing the relationship between accounting information and equity market values originates from seminal papers such as Beaver (1968); Ball and Brown (1968) and Miller and Modigliani (1959). The term 'value relevance' in the context of accounting information was first introduced by Amir, Harris and Venuti (1993). Subsequently, many studies have been done seeking to establish the ability of accounting information to explain or capture information that affect the value a firm.

Barth et al. (2001) contends that value relevance research examines the relationship between corporate disclosures and equity market values. This suggests testing whether disclosures explain cross-sectional variation in share prices. Barth et al. (2001) further notes that the studies of value relevance have been performed with the aim of assessing the characteristics of disclosures, primarily, relevance and reliability, as reflected in their relationship with a firm's value. According to the World Business Council for Sustainable Development, (WBCSD) (2000) corporate social responsibility is the ethical behaviour of a company towards society, 
management acting responsibly in its relationships with other stakeholders who have a legitimate interest in the business.

However, WBCSD \& United Nations Environment Programme Finance Initiative, (UNEP FI) (2010) observes that investors are not impressed, observing that there is lack of communication between the investors and people responsible for sustainability within the firms. In 2008, discussion sessions facilitated by the WBCSD and UNEP FI brought together analysts and sustainability experts in a bid to define how to move forward. According to Owolabi (2000) CSR reporting is perceived by investors as being important and over the years, studies have been carried out to examine the relationship between corporate social responsibility disclosure and value relevance of annual reports.

In an examination of the economic performance of sustainability reporting companies versus non-reporting companies in South Africa, Buys, Oberholzer and Andrikopoulos (2011) found that the economic performances of companies that voluntarily submit sustainability reports are better than those who do not support Global Reporting Initiatives (GRI) sustainability reporting guidelines. In a study "Environmental responsibility and firm performance: evidence from Nigeria", Ngwakwe (2009) evaluated the relationship between expenditure on sustainability variables against Return on Total Assets (ROTA). 'Environmental responsibility' was determined using disclosure on environmental and social issues above 50\%. Any disclosure less than $50 \%$ was assumed to be 'environmentally irresponsible'. The study concluded that sustainable business practices influenced the financial performance of firms (as measured by ROTA).

Clarkson et al. (2010) examined the impact of CSR disclosure on the cost of equity capital and firm's value, and on the public perception about a firm's environmental performance using actual toxic emissions data and firms' general disclosure propensity. They measured CSR disclosures in stand-alone environmental reports, CSR reports, and corporate websites using a disclosure index consistent with the Global Reporting Initiative disclosure framework for a sample of firms from the five most polluting industries in the US. The study concluded that CSR disclosures are incrementally informative for investors over current toxic emissions data in firm valuation analyses. It further observed that investors appear to use toxic emissions data to assess the firm risks and that CSR disclosure is positively associated with the Janis-Fadner coefficient, consistent with CSR disclosure enhancing non-investor stakeholder perception about firms' environmental performance. Basically the findings were interpreted to mean that investors consider the CSR report in making investment decisions, therefore inclusion of it in annual reports has an impact on the value relevance of the reports. 
Khaveh et al. (2012) investigated the relationship between environmental and social disclosure and shareholders' wealth for 15 public listed companies, which are listed in the Singapore Exchange main market. The research was aimed at three industries. The Findings of research demonstrated that there is significant and positive relationship between sustainability reporting and Singaporean companies' revenue.

In a study "When Does Corporate Sustainability Performance Pay off? The Impact of Country-Level Sustainability Performance", Chengyong, Qian, Taco and Dirk (2018) hypothesized that the financial effect of corporate sustainability disclosure has an inverse relationship with countrylevel sustainability performance because stakeholders will take a firm's sustainability improvement for granted in countries with good social and environmental performance. The results agreed with the hypothesis and were interpreted to mean that sustainability management can be a source of a competitive advantage for firms based in emerging economies, where in general the level of sustainability performance is relatively low. Basically these findings imply that corporate social responsibility disclosure has a relationship with the market value of equity.

Some studies have however arrived at a different conclusion. Jones, Frost and Der Laan (2009) carried out an examination of the market returns and financial performance of entities engaged in sustainability reporting in Australia. The study observed a negative and weak association. In a study "Are Stock Markets Influenced by Sustainability Matter? Evidence from European Countries", Moneva and Ortas (2008) found no association between corporate social responsibility disclosure and share's returns. In a study, Murray et al. (2006) sought to establish if financial markets in the United Kingdom care about social and environmental disclosures. They found no relationship between social and environmental disclosures and financial market performance.

From the foregoing empirical literature, results and conclusions are mixed and inconclusive findings still exist with respect to the relationship between value relevance of annual reports (as measured by the market value of equity) and the CSR disclosure included therein. The alternative hypothesis for this study states that corporate social responsibility disclosure has a significant relationship with the value relevance of annual reports for listed banks in Kenya.

\section{Research Methodology}

This study adopted a survey research design. The study population was the eleven banks listed on the Nairobi Securities Exchange at the time of this study. Ten banks listed on the Nairobi Securities Exchange over the entire period of study were selected for the study. Primary data was 
collected through survey questionnaires which were administered on the respondents who were financial analysts at a total of sixty one Kenya's Capital Markets Authority (CMA) licensed firms (investment banks, stock brokers, fund managers and investment advisers) as at 30 April 2016. The desk study method was used for secondary data which was obtained from the corporate action register by NSE, the NSE handbook, the daily market statistics from the NSE data and annual reports of the banks.

Sixty annual reports by the ten banks listed at the NSE over the entire period from year 2010 to year 2015 were studied. Data collection tool comprised of a tabular checklist which was used to collect data on the average market prices of the firms' shares and data on non-financial information included by the firms in their annual reports. From the corporate action register, the dates when annual reports were released for each year from 2010 to 2016 (for the period covered by the annual reports of years 2010 to 2015) were obtained. From the release date of a period's annual reports to the date of release of the subsequent period's annual reports, the closing weekly market price per share was obtained as recorded in the NSE market statistics data. The average market price per share, calculated by dividing the aggregate market price per share with actual the number weeks, was then filled in the checklist.

Content analysis was based on word frequency. According to Thomas, Céline, and Ludwig (2013) providing information on a specific topic in annual reports entails the use of related words more often. On this basis, observation of a distinct group of words in a disclosure can be taken as an indicator of the provision of specific information. Building on this perspective, an index to measure the information of interest in the subject disclosure using word frequencies was originated.

A list of pre-determined words (in order of relevance) relating to some five elements of social responsibility disclosure as itemized by Robb et al. (2001) in an analysis based on the 1994 Jenkins Committee report, was generated using OneLook dictionary. In an attempt to reduce the amount of data, only the first two hundred and fifty were used. Content analysis program ATLAS.ti 8 was then used obtain a list words and their frequencies, used in a total of sixty CSR disclosures included in the annual reports ten banks from year 2010 to year 2015. Ms Excel 2007 was then used to validate the ATLAS.ti 8 output against the OneLook dictionary list. In line with prior research that has identified word frequency as a sign for cognitive centrality (Duriau et al., 2007 and Abrahamson and Hambrick, 1997) the aggregate of frequency of the ten most used relevant words (as per the OneLook dictionary list) was then entered in the checklist.

The regression model used in this study was: $M V_{i}=\beta_{0}+\beta_{1} X_{i}+\varepsilon$ 
Where:

MV = Market Value of Equity

$\mathrm{X}=$ Corporate social responsibility disclosure

$\beta_{1}=$ the coefficient of $\mathrm{X}_{\mathrm{i}}$ for $\mathrm{i}=0,1 \ldots$

$\varepsilon=$ Random "error" assumed to have a $N(0, \sigma 2)$ distribution

\section{Analysis, Findings and Discussions}

The study used average market price per share to measure the valuerelevance of annual reports which was the dependent variable. The independent variable was corporate social responsibility disclosure. The study sought to test the hypothesis that corporate social responsibility disclosure does not have a significant relationship with the value relevance of annual reports for listed banks in Kenya. The findings are presented in this section.

\section{Descriptive Analysis}

The study computed the descriptive statistics of the secondary data on study variables. These included mean, standard deviation, minimum and maximum. The results are presented in table 1 .

Table 1: Descriptive Statistics of the Study Variables

\begin{tabular}{llrrrrrr}
\hline Variables & & 2010 & 2011 & 2012 & 2013 & 2014 & 2015 \\
\hline $\begin{array}{l}\text { Corporate social } \\
\text { responsibility } \\
\text { disclosure }\end{array}$ & & & & & & & \\
& Mean & 55.60 & 56.70 & 74.00 & 67.00 & 67.70 & 110.30 \\
& Std. Deviation & 10.36 & 4.71 & 18.85 & 19.41 & 19.60 & 14.54 \\
& Minimum & 17.00 & 35.00 & 25.00 & 24.00 & 13.00 & 40.00 \\
& Maximum & 139.00 & 77.00 & 234.00 & 233.00 & 233.00 & 168.00 \\
Average MPS & & & & & & \\
& Mean & 52.89 & 51.20 & 77.08 & 96.51 & 77.72 & 57.68 \\
& Std. Deviation & 18.97 & 20.20 & 28.94 & 33.51 & 26.76 & 21.02 \\
& Minimum & 14.81 & 12.48 & 16.87 & 16.80 & 14.07 & 7.89 \\
& Maximum & 204.58 & 213.83 & 298.45 & 326.85 & 251.48 & 198.88 \\
\hline
\end{tabular}

Five statements relating to corporate social responsibility disclosure were also presented to financial analysts at CMA's licensed firms (investment banks, stock brokers, fund managers and investment advisers) in a questionnaire. The descriptive results of corporate social responsibility disclosure are presented in table 2 .

Table 2: Descriptive Results of Corporate Social Responsibility Disclosure

\begin{tabular}{lrrrrrrr}
\hline & $\begin{array}{c}\text { Strongly } \\
\text { disagree }\end{array}$ & Disagree & Neutral & Agree & $\begin{array}{r}\text { Strongly } \\
\text { agree }\end{array}$ & Mean & $\begin{array}{r}\text { Std } \\
\text { Dev }\end{array}$ \\
\hline $\begin{array}{l}\text { Contribution to } \\
\text { economic development }\end{array}$ & $5.9 \%$ & $3.9 \%$ & $39.2 \%$ & $20.6 \%$ & $30.4 \%$ & 3.66 & 1.13
\end{tabular}


Relative bargaining power of resource providers $4.9 \%$ $1.0 \%$

Number of employees and employees'

incentives

$2.9 \%$

$5.9 \%$

$26.5 \%$

$37.3 \%$

$27.5 \% \quad 3.80$

1.01

Employees'

involvement and

fulfilment

$2.0 \%$

$7.8 \%$

$43.1 \%$

$26.5 \%$

$20.6 \%$

3.56

0.97

Relative bargaining

power of customers

$5.9 \%$

$3.9 \%$

$23.5 \% \quad 34.3 \%$

$32.4 \%$

3.83

1.11

The study sought to find out the view of the respondents on the claim that inclusion of information on the contribution to economic development by listed banks in the corporate social responsibility disclosure in their annual reports was useful for decisions on investment in their shares. The finding revealed that $30.4 \%$ of the respondents strongly agreed, $20.6 \%$ agreed while $39.2 \%$ were neutral. Those who disagreed were $3.9 \%$ while $5.9 \%$ strongly disagreed. The findings also showed that $28.4 \%$ and $27.5 \%$ of the respondents agreed and strongly agreed respectively with the statement that the inclusion of relative bargaining power of resource providers by listed banks in their corporate social responsibility disclosure was useful for decisions on investment in the banks' shares. Further, 37.3\% and 27.5\% agreed and strongly agreed respectively that decisions on investment in the shares of listed banks were informed by inclusion of number of employees and employees' incentives in the corporate social responsibility disclosure in their annual reports.

The study also sought to establish the view of respondents on the claim that inclusion of employees' involvement and fulfilment by listed banks in their annual reports was important for decisions on investment in the banks' shares. The results presented in table 2 showed that $43.1 \%$ of the respondents were neutral, $26.5 \%$ agreed while $20.6 \%$ strongly agreed. To the claim that disclosure of the relative bargaining power of customers by banks in their annual reports informed decisions on investment in the banks' shares, $34.3 \%$ agreed, $32.4 \%$ strongly agreed while less than $10 \%$ either strongly disagreed or disagreed with the statement.

These findings generally implied that corporate social responsibility disclosures in the annual reports of listed banks in Kenya informed the decisions on investments in the banks' shares. The findings are in agreement with Khaveh et al. (2012) who studied the relationship between environmental and social disclosure and shareholders wealth for 15 public listed companies, which are listed in the Singapore Exchange main market and demonstrated that there is significant and positive relationship between sustainability reporting and shareholders wealth. A study by Richardson and 
Michael (2001) on the relationship between social responsibility disclosure and the cost of equity capital also concluded that there is a positive relationship between social responsibility disclosure and cost of equity capital. The findings are also in agreement with Cho, Lee and Pfeiffer (2013) who established that corporate social responsibility reporting is inversely related to information asymmetry. Cho, Lee and Pfeiffer (2013) further observed that the relationship can however only be found in firms that have less institutional investors, implying that informed investors are more likely to act upon information relating to corporate social responsibility. It is notable that this is because the high-net-worth institutional investors are more likely to employ the services of financial analysts in their investment decisions.

\section{Inferential Statistics Results}

This section present results of the correlation and regression analysis. Before proceeding with the analysis, several diagnostic tests were carried out to test how well the model fitted the data. All the inferential statistics were conducted using the secondary data.

\section{Diagnostic Tests}

The study performed tests on statistical assumptions, that is, test of regression assumption and statistic used. This included test of normality, homoscedasticity, multicollinearity, autocorrelation and Hausman test for model specification. The tests were conducted to make sure that the statistical analysis conducted adhered to regression assumption hence avoid spurious and bias findings. The findings are presented in table 3 .

Table 3: Diagnostic Tests Results

\begin{tabular}{|c|c|c|c|}
\hline Diagnostic Tests Results & Test Used & Criterion & Conclusion \\
\hline Normality Test & $\mathrm{K}-\mathrm{S}$ test & $p>0.05$ & Data was normally distributed \\
\hline Homoscedastic Test & $\begin{array}{l}\text { Breusch and } \\
\text { Pagan (1979) }\end{array}$ & $\begin{array}{l}\mathrm{p} \text {-value is } \\
\text { greater than } 0.05\end{array}$ & $\begin{array}{l}\text { Null hypothesis was accepted and } \\
\text { concluded that there was } \\
\text { homoscedasticity }\end{array}$ \\
\hline Serial Autocorrelation & $\begin{array}{l}\text { Breusch- } \\
\text { Godfrey test }\end{array}$ & $\mathrm{p}<0.05$ & $\begin{array}{l}\text { Residuals are not auto correlated ( } \mathrm{p}- \\
\text { value }=0.0001 \text { ) }\end{array}$ \\
\hline Multicollinearity & VIF & $\mathrm{VIF}<10.0$ & No threat of multicollinearity \\
\hline Hausman test & Chi-Square & $\mathrm{p}>0.05$ & $\begin{array}{l}\text { Prob }>\text { chi } 2=0.8675, \text { therefore null } \\
\text { hypothesis that a random effect } \\
\text { model is the best was not rejected. } \\
\text { The study hence used a random } \\
\text { effect regression model }\end{array}$ \\
\hline
\end{tabular}

\section{Correlation Results}

Correlation test was conducted to test the association between the independent and the dependent variable. According to Kothari (2014) the 
importance of correlation is to determine the extent to which changes in the value of an attribute is associated with the changes in the value of another attribute. This study used correlation to test the association between the corporate social responsibility disclosure and the average market price per share (MPS).

Table 4: Correlation Matrix

\begin{tabular}{lll}
\hline Correlations & Corporate social \\
Corporate social & Pearson & \\
responsibility disclosure & $\begin{array}{l}\text { Correlation } \\
\text { Sig. (2-tailed) }\end{array}$ & 1 \\
& Pearson & \\
& Correlation & 0.331 \\
Average MPS & Sig. (2-tailed) & 0.016 \\
& $\mathrm{~N}$ & 60 \\
\hline
\end{tabular}

The results in table 4 show that corporate social responsibility disclosure had a correlation value $\mathrm{r}=0.331$ and $\mathrm{p}$-value $=0.016$. The finding revealed a weak positive association between corporate social responsibility disclosure and average market price of shares. This finding implied that positive change in corporate social responsibility disclosure could occasion a positive response in average market price per share, (MPS) hence the value relevance of annual reports. The findings of this study concur with those of Richardson and Michael (2001) who observed a positive relationship between corporate social responsibility disclosure and cost of equity capital. Similarly, financial analysts who filled questionnaires in this study generally agreed that corporate social responsibility disclosure is useful for decisions on investment in shares. Cho, Lee and Pfeiffer (2013) also observed the relationship and additionally concluded that informed investors act upon information relating to corporate social responsibility.

\section{Regression Analysis Results}

The study used univariate regression analysis to test the effect of the independent variable on dependent variable. Results in the table 3 indicates a prob>chi2 value of 0.8675 which is greater than critical $p$ - value at $5 \%$ level of significance. This implies that the null hypothesis that a random effect model is the best was not rejected. The study hence employed random effect regression model to ascertain the relationship between corporate social responsibility disclosure and average market price per share (MPS). The findings are presented in table 5. 
Table 5: Corporate Social Responsibility Disclosure and Average MPS

\begin{tabular}{lrrrr}
\hline Average MPS & Coef. & Std. Err. & $\mathrm{z}$ & $\mathrm{P}>|\mathrm{z}|$ \\
\hline Corporate Social Responsibility Disclosure & 0.374854 & 0.112482 & 3.33 & 0.001 \\
Constant & 52.13793 & 21.31835 & 2.45 & 0.014 \\
& & & & \\
Wald $\mathrm{chi}^{2}=11.11$ & & & & \\
Prob $>\mathrm{chi}^{2}=0.0009$ & & & & \\
& & & & \\
R-squared $=0.1849$ & & & & \\
\hline
\end{tabular}

The findings revealed a Wald $\mathrm{chi}^{2}=11.11$ and Prob $>\mathrm{chi}^{2}=0.0009$ which implied that the model: Average MPS $=52.13793+0.374854$ (Corporate Social Responsibility Disclosure) $+\varepsilon$, was statistically significant. The findings further revealed an R-squared $=0.1849$ meaning $18.49 \%$ of the variation in average market price per share was accounted for by corporate social responsibility disclosure.

To further test the significance of regression relationship between corporate social responsibility disclosure and average market price per share, (MPS), the regression coefficient $(\beta)$, the intercept $(\alpha)$, and the significance of the coefficients in the model were subjected to the t-test to test the null hypothesis that the coefficients are zero. The results on the beta coefficient of the resulting model showed that the constant $\alpha=52.13793$ was significantly different from 0 , since the $\mathrm{p}$-value $=0.014$ was less than 0.05 . The coefficient $\beta=0.374854$ was also significantly different from 0 with a $\mathrm{p}$-value $=0.001$ which was less than 0.05 .

The results imply that a unit change in corporate social responsibility disclosures will result in 0.374854 units change in average market price per shares (MPS). This confirms that there is a significant positive relationship between corporate social responsibility disclosure and average MPS of the listed bank in Kenya. The findings imply that corporate social responsibility disclosure has a positive influence on value relevance of annual reports as measured by average MPS. The findings of this study concur with those of Richardson and Michael (2001) who observed a positive relationship between corporate social responsibility disclosure and cost of equity capital. Similarly, Clarkson et al. (2010) concluded that CSR disclosure is positively associated with the Janis-Fadner coefficient, consistent with CSR disclosure enhancing non-investor stakeholder perception about firms' environmental performance.

\section{Conclusion and Recommendations}

The study observed significant explanatory power of corporate social responsibility disclosure on value relevance of annual reports. 
Based on the finding, the study concluded that inclusion of corporate social responsibility disclosure by a firm in its annual reports improves the perception of investors and impacts on the value relevance of annual reports. This disclosure is indeed important to investors and other users of annual reports.

Currently in accounting reporting, the auditor is not obliged to formally audit corporate social responsibility disclosure and other nonfinancial disclosures. Instead, the auditor just reviews the accounting narratives to ascertain if the narratives are consistent with the financial statements. This study recommends an expanded role of the auditor in reviewing the corporate social responsibility disclosure and other accounting narratives. The study also recommends more guidelines and regulations in relation to non-financial disclosures to ensure that firms put clearer information in the hand of investors.

\section{References:}

1. Aboody, D., Hughes, J., \& Liu, J. (2002). Measuring Value Relevance in a (Possibly) Inefficient Market. Journal of Accounting Research , 40, 965-986.

2. Abrahamson, E., \& Hambrick, D. (1997). Attentional homogeneity in industries: the effect of discretion. Journal of Organizational Behavior , 18, 513-532.

3. Adedeji, S., \& Kajola, S. O. (1998). Cost Accounting: Concept, Analysis and Use for Decision Making. CESAP, Ago-Iwoye.

4. Alan, M., Donald, S., \& David, P. (2006). Do financial markets care about social and environmental disclosure? Accounting, Auditing \& Accountability Journal, 228-255.

5. Alvarez, I. G., Sanchez, I. M., \& Domınguez, L. R. (2008). Voluntary and compulsory information disclosed online: The effect of industry concentration and other explanatory factors. Online Information Review, 32(5), 596-622.

6. Amir, E., Harris, T. S., \& Venuti, E. K. (1993). A Comparison of the Value- Relevance of U.S. Versus Non-U.S. GAAP Accounting Measures Using Form 20-F Reconciliations. Journal of Accounting Research, 31, 230-264.

7. Aylin, P. A., \& Tuba, B. (2014). Effect of Non Financial Information on Financial Performance: Evidence from Turkey. Lale Karabiyik.

8. Ball, R., \& Brown, P. (1968). An empirical evaluation of accounting income numbers. Journal of Accounting Research , 6(2): 159-178.

9. Barth, M. E., Beaver, W., \& Landsman, W. (2001). The Relevance of the Value Relevance Literature For Financial Accounting Standard Setting: Another View. Journal of Accounting and Economics . 
10. Beaver, H., \& Dukes. (1972). Interperiod tax allocation earnings expectations and the behavior of security prices. Accounting Review, 47: 320-418.

11. Beaver, W. (1968). The information content of annual earnings announcements. Journal of Accounting Research 1968 , 6, 67-92.

12. Belinda, H., \& David, W. (2008). The Use of Non-Financial Information: What Do Investors Want. Boston: The Boston College Center for Corporate Citizenship.

13. Benoit, S., Colletaz, G., \& Hurlin, C. (2014). A theoretical and empirical comparison of systemic risk measures. HEC Paris.

14. Buys, P., Oberholzer, M., \& Andrikopoulos, P. (2011). An investigation of the economic performance of sustainability reporting companies versus non-reporting companies: A South African perspective. Journal of Social Sciences , 151-158.

15. Chengyong, X., Qian, W., Taco, V., \& Dirk, D. (2018). When Does Corporate Sustainability Performance Pay off? The Impact of Country-Level Sustainability Performance. Ecological Economics .

16. Cho, S., Lee, Y., \& Pfeiffer, R. (2013). Corporate social responsibility performance and information asymmetry. Journal of Accounting and Public Policy, 32(1), 71-83.

17. Claessens, S. (2006). Corporate governance and development. The World Bank Research Observer, 21 (1), 91-122.

18. Clarkson, P. M., Fang, X. H., Li, Y., \& Richardson, G. (2010). The relevance of environmental disclosures for investors and other stakeholder groups: Are such disclosures incrementally informative?

19. Connelly, B., Certo, S., Ireland, R., \& Reutzel, C. (2011). Signaling theory: a review and assessment. Journal of Management , 37 (1), 3967.

20. Cytonn . (2015). Kenya Listed Commercial Banks Analysis.

21. Dan, S., Oliver, Z., Albert, T., \& Yong, G. (2011). Voluntary Nonfinancial Disclosure and the Cost of Equity Capital: The Initiation of Corporate Social Responsibility Reporting. The Accounting Review, 59-100.

22. Daniel, K. (2015). The Politics of Corporate Transparency and the Struggles over the Non-Financial Reporting Directive 2014/95/EU.

23. Depoers, F. (2000). A cost benefit study of voluntary disclosure: some empirical evidence from French listed companies. European Accounting Review , 9(2), 245-263.

24. Derwall, J., Koedijk, K., \& Ter Horsta, J. (2010). A Tale of ValuesDriven and Profit-Seeking Social Investors. ECCE.

25. Dhiaa, S. (2012). Impact of non accounting information on the value relevance of accounting information: the case of Jordan. 
International Journal of Business and Social Research (IJBSR) , Volume -2.

26. Duriau, V., Reger, R., \& Pfarrer, M. (2007). A Content Analysis of the Content Analysis Literature in Organization Studies: Research Themes, Data Sources, and Methodological Refinements, Organizational Research Methods.

27. Gray, R., Kouhy, R., \& Lavers, S. (1995a). Corporate social and environmental reporting: a review of the literature and a longitudinal study of UK disclosure. Accounting, Auditing and Accountability Journal , Vol. 8, No. 2,47-77.

28. Hassan, O., Giorgioni, G., Romilly, P., \& Power, D. (2011). Voluntary disclosure and risk in an emerging market. Journal of Accounting in Emerging Economies , (1), 33-52.

29. Healy, P., \& Palepu, G. (2001). Information asymmetry, corporate disclosure, and the capital market: a review of the empirical disclosure literature. Journal of Accounting and Economics , Vol. 31 Nos 1/3, 405-40.

30. Inchausti, B. (1997). The influence of company characteristics and accounting regulation on information disclosed by Spanish firms. European Accounting Review , 6(1), 45-68.

31. IASB. (2011). International Accounting Standard 1. International Accounting Standard Board

32. Ittonen, K. (2010). A theoretical examination of the role of auditing and the relevance of audit reports. University of Vaasa.

33. Jones, S., Frost, G., \& Laan, S. (2009). An empirical examination of the market returns and financial performance of entities engaged in sustainability reporting. Australian Accounting Review , 78-87.

34. Khaveh, A., Nikhashemi, S. R., Yousefi, A., \& Haque, A. (2012). Voluntary sustainability disclosure, revenue and shareholders wealth - A perspective from Singaporean companies. Business Management Dynamics , 6-12.

35. Kristandl, G., \& Bontis, N. (2007). The impact of voluntary disclosure on cost of capital estimates in a temporal setting. Journal of Intellectual Capital , 577-94.

36. Laan, S. (2009). The role of theory in explaining motivation for corporate social disclosures: voluntary disclosures vs 'Solicited' disclosures. Australasian Accounting Business and Finance Journal , 3(4), 15-29.

37. Lev, B. (2000). Intangibles - Management, Measurement, and Reporting. Washington, DC: Brookings Institution Press.

38. Meyer, C. (2007). Shareholder Value Accounting - the Value Relevance of Financial Statement Data and the Determinants of 
Accounting Method Choices. Retrieved August 6, 2015, from http://www.research.unizh.ch.

39. Modigliani, F., \& Miller, M. (1959). The Cost of Capital, Corporation Finance, and the Theory of Investment: Reply. American Economic Review , 49(4), 655-669.

40. Moneva, J. M., \& Ortas, E. (2008). Are stock markets influenced by sustainability matter? Evidence from European countries. International Journal of Sustainability Economy.

41. Murray, A., Sinclair, D., Power, D., \& Gray, R. (2006). Do financial markets care about social and environmental disclosure? Further evidence and exploration from the UK. Accounting, Auditing and Accountability Journal , 19, 228-255.

42. Negah, M. (2008). Liberalisation and the value relevance of Accrual Accounting Information: Evidence from the Johannesburg Securities Exchange. , Afro -Asian Journal of Finance and Accounting , 81104.

43. Ngwakwe, C. C. (2009). Environmental responsibility and firm performance: evidence from Nigeria. International Journal of Human and Social Sciences .

44. Nik Ahmad, N., \& Sulaiman, M. (2004). Environmental disclosures in Malaysia annual reports: A legitimacy theory perspective. International Journal of Commerce and Managemet , 14(1), 44-58.

45. Ocean, T. (2015). Intangible Asset Market Value. Ocean.

46. OECD. (2004). OECD Principles of Corporate Governance. Paris: OECD Publications Service, The Organisation for Economic Cooperation and Development.

47. Ohlson, J. (1999). Accounting Earnings, Book Value and Dividends: The Theory of the Clean Surplus Equation (Part I).

48. Omokhudu, O., \& Ibadin, P. (2015). The Value Relevance of Accounting Information: Evidence from Nigeria. Accounting and Finance Research, Vol. 4, No. 3; 2015.

49. Owolabi, A. A. (2000). An evaluation of managers' and accounting professionals' perception of environmental issues and reporting in South Western Nigeria. Ile-Ife, Nigeria: Obafemi Awolowo University.

50. Oyerinde, D. (2011). Value- relevance of accounting information in the Nigerian stock market. Unpublished Ph.D. dissertation, Covenant University, Nigeria .

51. Richardson, A. J., \& Michael, W. (2001). Social disclosure, financial disclosure and the cost of equity capital. Kingston, Canada: School of Business, Queen's University. 
52. Robb, S. W., Single, L. E., \& Zarzeski, M. (2001). Nonfinancial disclosures across Anglo- American countries. Journal of International Accounting, Auditing and Taxation , 71-83.

53. Ronnie, L. (2009). Voluntary corporate governance disclosure, firm valuation and dividend payout: evidence from Hong Kong listed firms. Unpublished Ph.D. dissertation.

54. Schuster, P., \& O'Connell, V. (2006). The trend toward voluntary corporate disclosures. Management Accounting Quarterly, 7(2), 1-9.

55. Swati, M. (2016). A Review on the Literature of Value Relevance of Non Financial Variables or Information .

56. Thomas, B., Céline, B., \& Ludwig, M. (2013). Advancing ValueRelevance Studies on Non-Financial Information: A Complementary Approach . University of St.Gallen, Switzerland.

57. Topazio, N. (2013). Consultation Draft of the International integrated reporting. Chartered Institute of Management Accountants.

58. Van der Laan, S. (2009). The role of theory in explaining motivation for corporate social disclosures: voluntary disclosures vs 'solicited' disclosures. Australasian Accounting Business and Finance Journal, $3(4)$.

59. Vijitha, P., \& Imalathasan, P. (2014). Value relevance of published financial statements with special emphasis on. International Research Journal of Finance and Economics , 17(1), 1450-2887.

60. Vishnani, S., \& Shah, B. (2008). International differences in the relation between financial Reporting Decisions and Value Relevance of Published Financial Statements- with Special Emphasis on Impact of Cash Flow Reporting. International Research Journal of Finance and Economics , 17(1), 1450-2887.

61. Wang, J., Gang, F., \& Chao, L. (2013). Accounting Information and Stock Price Reaction of Listed Companies: Empirical Evidence from 60 Listed Companies in Shanghai Stock Exchange. Journal of Business \&Management, 2(2), 11-21.

62. Watson, A., Shrives, P., \& Marston, C. (2002). Voluntary disclosure of accounting ratios in the UK. British Accounting Review , 34, 289313.

63. WBCSD. (2000). Meeting Changing Expectations. Geneva: World Business Council for Sustainable Development .

64. WBCSD and UNEP FI. (2010). Translating ESG into sustainable business value: Key insights for companies and investors. The Asset Management Working Group.

65. Weygandt, J., Kieso, D., \& Kimmel, P. (2003). Financial accounting (UOPHX special edition series). New York: John Wily and Sons. 
66. Xueming, L., \& Bhattacharya, C. (2006). Corporate Social Responsibility, Customer Satisfaction, and Market Value. Journal of Marketing , 1-18. 